\title{
The impact of requiring completion of an online infection control course on health professionals' intentions to comply with infection control guidelines: A comparative study
}

\author{
Annalee Yassi MD MSc FRCPC ${ }^{1,2}$, Elizabeth A Bryce MD FRCPC ${ }^{3,4}$, Deirdre Maultsaid MEd ${ }^{4}$, \\ Helen Novak Lauscher Phd ${ }^{5}$, Kun Zhao MD MSc ${ }^{1}$
}

\begin{abstract}
A Yassi, EA Bryce, D Maultsaid, H Novak Lauscher, K Zhao. The impact of requiring completion of an online infection control course on health professionals' intentions to comply with infection control guidelines: A comparative study. Can J Infect Dis Med Microbiol 2009;20(1):15-19.
\end{abstract}

BACKGROUND: Ensuring good infection control practice in health care facilities is a constant concern, yet evidence shows that the compliance of health care professionals with proper procedures is lacking, despite the existence of guidelines and training programs. An online infection control module was developed to provide ready access to training. Controversy exists about whether successfully completing such a course should be mandatory or strongly encouraged for all health care professionals. The objective of the present study was to compare the perception of safety culture and intention to comply with infection control guidelines in professionals who were required by their supervisors to take the course, and those who did so voluntarily.

METHODS: Survey responses on learning environment, safety climate and intention to comply with infection control guidelines in health care professionals who were required to take the course (supervisor-required group $[\mathrm{n}=143]$ ) and those who took the same course voluntarily (voluntary group $[n=105]$ ) were compared. Because randomization was thought to be too difficult to implement in the policy context in which the study was conducted, significant differences between the two groups were taken into account in the analysis.

RESULTS: Those required to take the course had a significantly better perception of the institutional safety climate $(\mathrm{P}<0.001)$, and had a higher reported intention to comply with infection control guidelines $(\mathrm{P}=0.040)$ than those who took the course voluntarily.

DISCUSSION: Requiring that staff complete a 30 min interactive online infection control module increased their intention to comply with infection control guidelines compared with those who voluntarily accessed this material based on promotional material. Consideration should be given to making the successful completion of an online infection control module a requirement for all health care professionals.
Les répercussions d'obliger des professionnels de la santé à recevoir une cyberformation sur le contrôle des infections sur leurs intentions de respecter les lignes directrices en matière de contrôle des infections : Une étude comparative

HISTORIQUE : Il est toujours préoccupant d'assurer de bonnes pratiques de contrôle des infections dans les établissements de santé, mais selon les données probantes, les professionnels de la santé ne respectent pas les précautions nécessaires, malgré l'existence de lignes directrices et de programmes de formation. On a élaboré un cybermodule sur le contrôle des infections afin d'offrir un accès facile à la formation. On ne s'entend pas pour établir si tous les professionnels de la santé devraient être obligés ou fortement encouragés à le suivre. La présente étude visait à comparer la perception de la culture de la sécurité et l'intention de respecter les lignes directrices de contrôle des infections chez les professionnels obligés par leur superviseur à suivre le cours et chez ceux qui le suivaient volontairement.

MÉTHODOLOGIE : On a comparé les réponses au sondage sur le milieu d'apprentissage, le climat de sécurité et l'intention de respecter les lignes directrices sur le contrôle de la sécurité des professionnels de la santé tenus de suivre le cours (groupe obligé par le superviseur [n=143]) à celles des professionnels qui l'avaient suivi volontairement (groupe de volontaires $[\mathrm{n}=105]$ ). Puisqu'on jugeait l'aléation trop difficile à obtenir dans le contexte politique de l'étude, on a tenu compte d'importantes différences entre les deux groupes lors de l'analyse.

RÉSULTATS : Ceux qui avaient dû suivre le cours avaient une perception beaucoup plus positive du climat de sécurité de l'établissement $(\mathrm{P}<0,001)$ et déclaraient une plus grande intention de respecter les lignes directrices de contrôle des infections $(\mathrm{P}=0,040)$ que ceux qui l'avaient suivi volontairement.

EXPOSÉ : Exiger que les membres du personnel participent à un cybermodule interactif de 30 minutes sur le contrôle des infections accroît leur intention de respecter les lignes directrices de contrôle des infections par rapport aux professionnels de la santé qui y accèdent volontairement après avoir vu la documentation promotionnelle. Il faut envisager de rendre obligatoire la participation des professionnels de la santé à un cybermodule sur le contrôle des infections.

Key Words: Compliance; Hand hygiene; Infection control; Online education; SARS; Training

${ }^{1}$ School of Population and Public Health; ${ }^{2}$ Department of Medicine, University of British Columbia; ${ }^{3}$ Vancouver Coastal Health Authority;

${ }^{4}$ Department of Pathology; ${ }^{5}$ Department of Continuing Professional Development and Knowledge Translation, University of British Columbia,

Vancouver, British Columbia

Correspondence: Dr Annalee Yassi, 430 - 2206 East Mall, University of British Columbia, Vancouver, British Columbia V6T 123.

Telephone 604-827-3010, fax 604-822-9810, e-mail annalee.yassi@ubc.ca

Received for publication May 28, 2008. Accepted September 12, 2008 
$\mathrm{T}$ he severe acute respiratory syndrome (SARS) outbreak drew attention to the transmissibility of infectious agents, and echoed the findings of others regarding the role of inadequate training on infection control measures among health care workers as an explanation for nosocomial spread and occupationally acquired infection $(1,2)$. Despite guidelines $(3,4)$ aimed at reducing hospital-acquired infections, compliance with best practices is still lacking (5-7).

The most consistent determinant of adopting safe work practices has been shown to be safety climate; that is, employees' perception of organizational commitment to safety $(8-11)$. Our previous research $(12-14)$ indicated that an important demonstration of an organization's commitment to safety is the provision of appropriate workplace education. However, time constraints and demanding workloads limit infection control education at group sessions; textbased manuals are inadequate in teaching proper barrier selection and use. A self-paced, flexible, online format is purported to be well-suited to adult learners and to the field of infection control (15-17).

While providing training generally improves safety climate, making a workplace control measure mandatory is often met with resistance - particularly if the workforce is unclear as to the importance of this measure. It is not known whether the objective of improving infection control, occupational health and safety climate in the hospital environment would be better served by requiring all health professionals to successfully complete a course in infection control as opposed to encouraging them to do so. Therefore, the objective of the present study was to compare the perception of safety culture and intention to comply with infection control guidelines in health professionals who were required by their supervisors to take an online learning course, and those who did so voluntarily, based on having seen promotional material.

\section{METHODS}

\section{Study population}

The target population was all health care professionals within an urban health region who were working in acute, rehabilitation, residential, community and pediatric facilities, and who had taken the infection control course. Some supervisors and clinical orientation coordinators required that some staff take the course (Table 1); the course was also promoted using newsletters, posters and word-of-mouth. To take the course, staff had to register on the learning management system. Survey respondents self-assessed as to whether their taking the course was supervisor-required or voluntary. While supervisors required taking the course, participation in the present study, which consisted of completing the research survey, was not required, as consistent with behavioural ethics requirements.

\section{The intervention}

Because there was growing awareness of the importance of standardized infection control training within the health region, by the start of the study (July 2006), executives in staff development, patient safety and occupational health had endorsed the course as required learning for new staff and students. New staff received the course as part of a four-day program, which also emphasized other health and safety issues, such as musculoskeletal injury prevention and waste management. Students received the course as part of an online orientation to health and safety. No other standardized infection control course was offered within the health region, although the infection control program provided in-services regularly. The 30 min online module used graphics, videos and text to teach the principles of infection control, how to clean one's hands, and how to select and use personal barriers. The course was on the health region's Course Catalogue Registration System (learning management system), and was available to all health care workers across the continuum from acute care to rehabilitation to community care, from any computer with Internet access (18).

\section{Survey}

From July 2006 until June 2007, participants were invited to link to a survey after they had taken the module and before the posttest. In accordance with institutional ethical guidelines, by completing the survey, the participants consented to participate. The survey (based on two previously validated surveys [12,19]) took approximately $15 \mathrm{~min}$ and was comprised of 27 questions related to the following - participants' demographics, views on the course content and structure, workplace learning environment, safety climate and personal intention to comply with infection control guidelines. Some questions provided open text boxes for answers, while some required answers on a seven-point subjective measurement scale (Likert scale) ranging from 1, 'strongly disagree' to 7, 'strongly agree'.

\section{Analysis}

A nonparametric $\chi^{2}$ test was used to examine the differences between the supervisor-required and voluntary groups. After logarithmically transforming the data for the dependent variables, and using 'reasons for taking the module' as the categorical variable, multiple linear regression models were applied to examine differences between the two groups (voluntary versus supervisor-required). The adjusted variables in the model were age, years at the job, years at the facility, occupation and whether the respondent had patient contact. Before performing the multiple linear regressions, the multicollinearity between predictors of age, years at the job and years at the facility was assessed with a tolerance value set to greater than 0.10 and a variance inflation factor set to less than 10. All tests were two-sided, with significance levels of $\mathrm{P} \leq 0.05$ estimated from SPSS version 14.0 (SPSS Inc, USA). Partially missing values were automatically excluded.

\section{RESULTS}

Of all course users $(n=744)$ in the time period between July 2006 and June 2007, 253 (34\%) responded to the survey. Of the 253, 148 identified themselves as having taken the course as supervisor-required, and 105 identified themselves as being in the voluntary group. Of the 253 respondents, $88 \%$ were women, $58 \%$ worked in acute care settings, $53 \%$ were nurses and $85 \%$ reported having some patient contact in their work. As shown in Table 1, the voluntary group, who took the course on their own initiative, was older and more experienced on the job and in their facilities. This is expected because many participants in the supervisor-required group were required to take the course as part of their orientation $(43.24 \%)$, or as part of a student program $(29.72 \%)$. There were also significantly more administrators, managers, educators and volunteers in the voluntary group. Of those who chose to take the course on their own initiative, $71.4 \%$ reported patient contact compared with $91.9 \%$ of the supervisor-required group $(\mathrm{P}<0.001)$. There were 
TABLE 1

Comparison of participant characteristics in the two groups: Voluntary and supervisor-required

\begin{tabular}{|c|c|c|c|}
\hline Characteristic & $\begin{array}{l}\text { Voluntary, } \\
\text { n (\%) }\end{array}$ & $\begin{array}{c}\text { Supervisor-required*, } \\
\text { n (\%) }\end{array}$ & $\mathbf{P}$ \\
\hline Total & 105 (41.5) & $148(58.5)$ & $N / A$ \\
\hline \multicolumn{4}{|l|}{ Sex } \\
\hline Women & $90(89.0)$ & $116(87.2)$ & 0.070 \\
\hline Men & $11(11.0)$ & $17(12.8)$ & 0.257 \\
\hline \multicolumn{4}{|l|}{ Age group, years } \\
\hline$\leq 20$ & $1(1.0)$ & $3(2.3)$ & 0.317 \\
\hline $21-30$ & $24(23.8)$ & $75(56.4)$ & $<0.001$ \\
\hline $31-40$ & $28(27.7)$ & $34(25.6)$ & 0.446 \\
\hline $41-50$ & $26(25.7)$ & $13(9.8)$ & 0.037 \\
\hline$\geq 51$ & $22(21.8)$ & $8(6.0)$ & 0.011 \\
\hline \multicolumn{4}{|l|}{ Years at job } \\
\hline$<1$ & $13(12.9)$ & 44 (33.1) & 0.001 \\
\hline $1-5$ & $26(25.7)$ & $56(42.1)$ & 0.001 \\
\hline $6-10$ & $13(12.9)$ & $16(12.0)$ & 0.577 \\
\hline$>10$ & $49(48.5)$ & $17(12.8)$ & $<0.001$ \\
\hline \multicolumn{4}{|l|}{ Years at facility } \\
\hline$<1$ & $24(23.3)$ & 77 (57.9) & $<0.001$ \\
\hline $1-5$ & 39 (37.9) & $42(31.6)$ & 0.739 \\
\hline $6-10$ & $10(9.7)$ & $4(3.0)$ & 0.109 \\
\hline $11-15$ & $30(29.1)$ & $10(7.5)$ & 0.002 \\
\hline \multicolumn{4}{|l|}{ Occupation } \\
\hline Physicians & $3(3.0)$ & $7(5.3)$ & 0.206 \\
\hline Nurses & 49 (48.5) & 73 (54.9) & 0.030 \\
\hline $\begin{array}{l}\text { Allied health and } \\
\text { technologists }\end{array}$ & $17(16.8)$ & $14(10.5)$ & 0.590 \\
\hline $\begin{array}{l}\text { Administration, } \\
\text { management, } \\
\text { facilities, educators } \\
\text { and volunteers }\end{array}$ & $23(22.8)$ & $3(2.3)$ & $<0.001$ \\
\hline Students & $9(8.9)$ & $36(27.1)$ & $<0.001$ \\
\hline \multicolumn{4}{|l|}{ Facility } \\
\hline Acute & $56(55.4)$ & $80(60.2)$ & 0.040 \\
\hline $\begin{array}{l}\text { Rehabilitation/transition/ } \\
\text { residential care }\end{array}$ & 12 (11.9) & $23(17.3)$ & 0.063 \\
\hline Ambulatory care & $2(2.0)$ & $0(0.0)$ & 0.0 \\
\hline Community & $0(0.0)$ & $0(0.0)$ & 0.0 \\
\hline Unknown & $31(30.7)$ & $30(22.6)$ & 0.898 \\
\hline
\end{tabular}

The $n$ values fluctuate in the voluntary group; $n=133$ in the supervisor-required group. *Supervisors requiring the course, $n(\%)$ - clinical orientation program (64 [43.24], student coordinator (44 [29.72]), medical director (7 [4.72]), patient services manager (2 [1.3]) and unknown (31 [20.94]). N/A Not applicable

no differences between the two groups in the extent of selfassessed previous infection control knowledge or individual motivation for following infection control precautions. (Participants were asked if they followed precautions to protect themselves, their patients and families, and if they would follow precautions to influence their coworkers.)

In response to questions about the safety climate, participants agreed that the facilities ensure patient safety $(84 \%)$ and staff safety $(88 \%)$. Although aspects of the safety climate scored highly, $56 \%$ of respondents gave a neutral response when asked whether their coworkers encouraged them to follow infection control precautions or to take the infection control module.
TABLE 2

Comparison of the mean rank* in the two groups: Voluntary $(n=105)$ and supervisor-required $(n=148)$

\begin{tabular}{lccc}
\hline Survey answer & Voluntary & Supervisor-required & $\mathbf{P}^{\dagger}$ \\
\hline $\begin{array}{l}\text { Module is applicable } \\
\text { to work }\end{array}$ & 125.03 & 128.40 & 0.166 \\
$\begin{array}{l}\text { Module is satisfactory } \\
\text { Have previous knowledge } \\
\text { of infection control }\end{array}$ & 132.82 & 122.87 & 0.133 \\
$\begin{array}{l}\text { Learning environment exists } \\
\text { Learning opportunities }\end{array}$ & 109.95 & 126.41 & 0.869 \\
$\quad 104.12$ & 130.87 & 0.135 \\
$\begin{array}{l}\text { Safe available } \\
\text { Coworkers encourage }\end{array}$ & 115.13 & 135.16 & 0.059 \\
$\begin{array}{l}\text { infection control practice } \\
\text { Infection control is } \\
\text { important in the workplace }\end{array}$ & 108.04 & 127.06 & 0.065 \\
$\begin{array}{l}\text { The facility ensures } \\
\text { staff safety }\end{array}$ & 108.82 & 132.27 & 0.040 \\
$\begin{array}{l}\text { The facility ensures } \\
\text { patient safety }\end{array}$ & 109.25 & 131.70 & 0.021 \\
$\begin{array}{l}\text { Intend to comply with } \\
\text { infection control guidelines }\end{array}$ & 105.49 & 131.38 & 0.047 \\
\hline
\end{tabular}

*The mean rank was derived from calculating the average after incremental values on the Likert scale were assigned and the sum of those values multiplied by the number of respondents was totalled; ${ }^{\dagger}$ The $P$ value was derived from the multiple linear regression after adjusting for age, years at job, years at facility, occupation, method of module promotion and patient contact

There was no multicollinearity detected among predictors of age, years at the job or years at the facility in the regression model. All tolerance values were around 0.50 , and the variance inflation factor values were less than 2.50. There was a statistically significant difference in judging the safety climate $(\mathrm{P}<0.001)$. The logistic regression model also showed that there was a statistically significant difference between supervisorrequired and voluntary groups with respect to perceived importance of infection control in the workplace $(\mathrm{P}=0.040)$, the extent to which the facility ensures patient safety $(\mathrm{P}=0.047)$ and the extent to which the facility ensures staff safety $(\mathrm{P}=0.021)$ (Table 2). The supervisor-required group also indicated, at a significantly higher rate, that they would comply with infection control guidelines $(\mathrm{P}=0.040)$.

\section{DISCUSSION}

Our previous research (11-14) and that of others (9-10) suggest an important link between providing health and safety training to health professionals and the perceived safety climate in the organization. However, there have been no previous studies on the impact of supervisor-required versus voluntary training, or on the relationship of this variable to intention to comply with infection control guidelines. A randomized controlled trial would have been difficult to implement in this setting on this topic because the research team believed that it would not be possible to ask supervisors to randomly assign new hires and students into groups who were told that they 'must take the course' and those merely 'encouraged to take the course voluntarily', because, although, there were no institutional repercussions in place for not taking the course, the decision had already been made by the health authority to require a course such as this. It was possible, 
however, for supervisors to ask that all their new hires or students take the course, and generate an entirely voluntary group by advertising the course with posters, newsletters, e-mail promotions and other means. Although our two groups had some important demographic differences (notably many more students and new staff in the supervisor-required group compared with the voluntary group), we were able to control for these differences in the analysis. Volunteer participants tend to have an inherent bias in that they are already engaged and are more likely to make positive statements. The fact that we found that those required by their supervisor to take the course were actually more likely to make the positive statements about the safety climate, than those who took it on their own initiative is, therefore, quite noteworthy. It would especially appear that the dedicated training time provided to new staff is effective in generating a high intention to comply with guidelines. Further study would be necessary to ascertain the conditions under which experienced staff could develop a higher intention to comply.

In an era in which improving the safety climate in hospitals is an urgent imperative (20), the finding that those required to take the course had a higher expressed intention of complying with infection control guidelines (controlling for differences in occupation including student status, patient contact, years of experience and all other significant potential confounders), suggests that requiring all health care professionals to take a short online course in infection control may be a worthwhile policy for hospitals to consider.

There are many individual, environmental and organizational factors associated with a lack of compliance (13), and these may vary from one occupational group to another. For example, physicians are one group of health care professionals known to have less compliance with infection control practices $(5,21,22)$. As noted by Fordis et al (16), the evidence indicates that online learning is increasing among physicians, and that online continuing medical education can produce changes in physician knowledge comparable with those achievable with appropriately designed live interventions and changes in behaviour that have an impact on patient care. Physicians can also serve as important role models for other members of the health care team (23). Therefore, including physicians in the same policies that apply to other health care professionals with respect to this policy merits serious consideration. The local medical school has recently made the completion of this online infection control course mandatory; the local health region now requires the successful completion of this module as a condition for maintaining hospital privileges. Further research is required to determine whether expressed intention to comply with infection control guidelines translates into sustained clinical practice.

\section{CONCLUSION}

Requiring that health professionals complete a 30 min interactive online infection control module generates a higher intention to comply with infection control guidelines compared with those who voluntarily access this material. More importantly perhaps, it also increases perception of management commitment to infection control and improves perception of the safety culture of the organization. Serious consideration should be given to making the successful completion of a short online infection control module an important requirement for all health care professionals.
AUTHOR CONTRIBUTIONS: Drs Yassi and Bryce had full access to all of the study data, and they take responsibility for the integrity of the data and the accuracy of the analysis. Drs Bryce, Lauscher and Yassi contributed to the design and conduct of the study, and revised the manuscript critically for important intellectual content. Ms Maultsaid performed the data collection. Drs Bryce, Yassi and Zhao analyzed and interpreted the data. All of the authors participated in the preparation of the manuscript, and they all approved the version submitted for publication.

ACKNOWLEDGEMENTS: The authors thank the following: Justin LoChang (School of Population and Public Health, University of British Columbia) and Margaret Landstrom (Learning and Development, Children's and Women's Health Centre of British Columbia [Provincial Health Services Authority]) for their help in the study concept and design; Justin LoChang and Peter Choi (Learning and Development, Vancouver Coastal Health) for the acquisition of data; and Justin LoChang and Kun Zhao (who was paid a small fee, at a student rate, to provide technical assistance with statistical analysis) for the analysis and interpretation of data.

FUNDING/POLICY ISSUES: This survey was cosponsored by the Canadian Institutes of Health Research, Vancouver Coastal Health Authority and the British Columbia Centre for Disease Control (Provincial Health Services Authority) in a Partnership for Health Systems Improvement Grant, 2005-2008. Dr Yassi acknowledges her funding as a Tier 1 Canada Research Council (CRC) Chair-holder. Funding sources had no role in the design and conduct of the study; collection, management, analysis and interpretation of the data; and preparation, review or approval of the manuscript. The University of British Columbia Behavioural Research Ethics Board approved this research.

\section{REFERENCES}

1. Varia M, Wilson S, Sarwal S, et al. Investigation of a nosocomial outbreak of severe acute respiratory syndrome (SARS) in Toronto, Canada. CMAJ 2003;169:285-92.

2. Gamage B, Moore D, Copes R, Yassi A, Bryce E; The BC Interdisciplinary Respiratory Protection Study Group. Protecting health care workers from SARS and other respiratory pathogens: A review of the infection control literature. Am J Infect Control 2005;13:114-21.

3. Health Canada. Prevention and control of occupational infections in health care. An infection control guideline. Can Commun Dis Rep 2002;28(Suppl 1):1-264. <http://www.phac-aspc.gc.ca/publicat/ccdr-rmtc/02 vol28/ 28s1/index.html> (Version current at March 25, 2008).

4. Health Canada, Laboratory Centre for Disease Control, Division of Nosocomial and Occupational Infections. Routine practices and additional precautions for preventing transmission of infection in health care. Can Commun Dis Rep 1999;25(Suppl 4):1-142. <http://www.phac-aspc.gc.ca/ publicat/ccdr-rmtc/99vol25/25s4/index.html > (Version current at March 25, 2008).

5. Michalsen A, Delclos G, Felknor S, et al. Compliance with universal precautions among physicians. J Occup Environ Med 1997;39:130-7.

6. Gershon RR, Vlahov D, Flekonor SA. Compliance with universal precautions among health care workers at three regional hospitals. Am J Infect Control 1995;23:225-36.

7. Zoutman DE, Ford BD, Bryce E, et al. The state of infection surveillance and control in Canadian acute care hospitals. Am J Infect Control 2003;3:266-72.

8. Moore D, Gilbert M, Saunders S, Bryce E, Yassi A. Occupational health and infection control practices related to severe acute respiratory syndrome: Healthcare worker perceptions. AAOHN J 2005;53:257-66.

9. Gershon RR. Hospital safety climate and its relationship with safe work practices and workplace exposure incidents. Am J Infect Control 2000;28:211-21. 
10. Clarke SP, Sloane DM, Aiken LH. Effects of hospital staff and organizational climate on needlestick injuries to nurses. Am J Pub Health 2002;92:1115-9.

11. Yassi A, Hancock T. Patient safety - worker safety: Building a culture of safety to improve healthcare worker and patient well-being. Healthc Q 2005;8:32-8.

12. Yassi A, Lockhart K, Copes R, et al. Determinants of healthcare workers' compliance with infection control procedures. Healthc Q 2007;10:44-52.

13. Moore D, Gamage B, Bryce E, Copes R, Yassi A; The BC Interdisciplinary Respiratory Protection Study Group. Protecting health care workers from SARS and other respiratory pathogens: Organizational and individual factors that affect adherence to infection control guidelines. Am J Infect Control 2005;33:88-96.

14. Yassi A, Moore D, Fitzgerald JM, Bigelow P, Hon CY, Bryce E; The BC Interdisciplinary Respiratory Protection Study Group. Research gaps in protecting healthcare workers from SARS and other respiratory pathogens: An interdisciplinary, multi-stakeholder, evidence-based approach. J Occup Environ Med 2005;47:41-50.

15. Pullen D. An evaluative case study of online learning for healthcare professionals. J Contin Educ Nurs 2006;37:226-32.

16. Fordis M, King J, Ballantyne C, et al. Comparison of the instructional efficacy of Internet-based CME with live interactive
CME workshops: A randomized controlled trial. JAMA 2005;294:43-51.

17. Desai N, Philpott-Howard J, Wade J, Casewell M. Infection control training: Evaluation of a computer-assisted learning package. J Hosp Infect 2000;44:193-9.

18. Vancouver Coastal Health Authority, Occupational Health and Safety Agency for Healthcare in British Columbia, Provincial Health Services Authority. Infection Control Basics.

Creative Commons A, ND, NC, 2008. <https://ccrs.vch.ca> (Version current at March 25, 2008).

19. O'Boyle CA, Henly SJ, Duckett LJ. Nurses' motivation to wash their hands: A standardized measurement approach. Appl Nurs Res 2001;14:136-45.

20. Baker GR, Norton PG. Making patients safer! Reducing error in Canadian healthcare. Healthc Pap 2001;2:10-31.

21. Pittet D, Mourouga P, Perneger TV. Compliance with hand washing in a teaching hospital infection control program. Ann Intern Med 1999;130:126-30.

22. Lipsett P, Swoboda S. Handwashing compliance depends on professional status. Surg Infect 2001;2:241-5.

23. Lankford M, Zembower T, Trick W, Hacek D, Noskin G, Peterson L. Influence of role models and hospital design on hand hygiene of healthcare workers. Emerg Infect Dis 2003;9:217-23. 


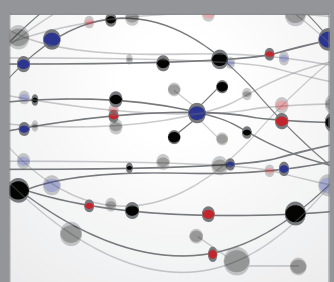

The Scientific World Journal
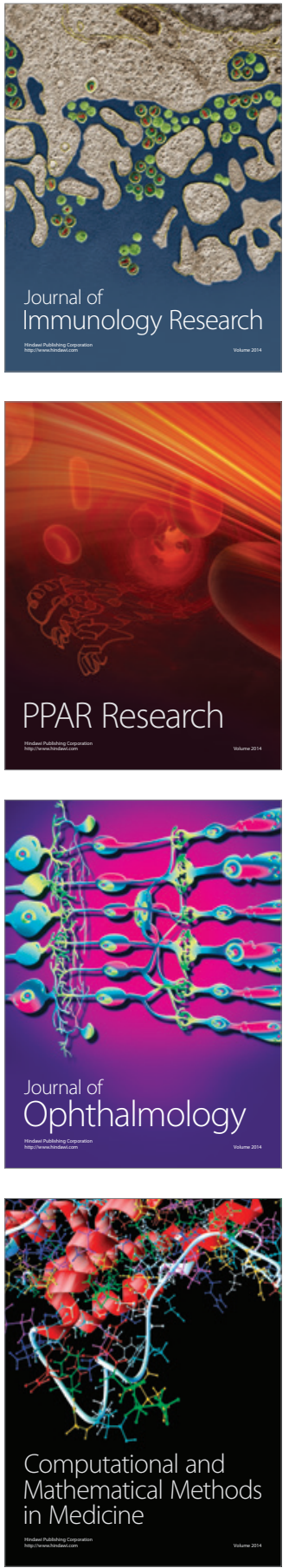

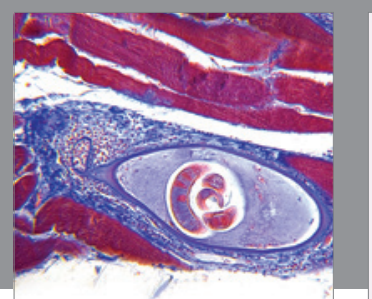

Gastroenterology Research and Practice

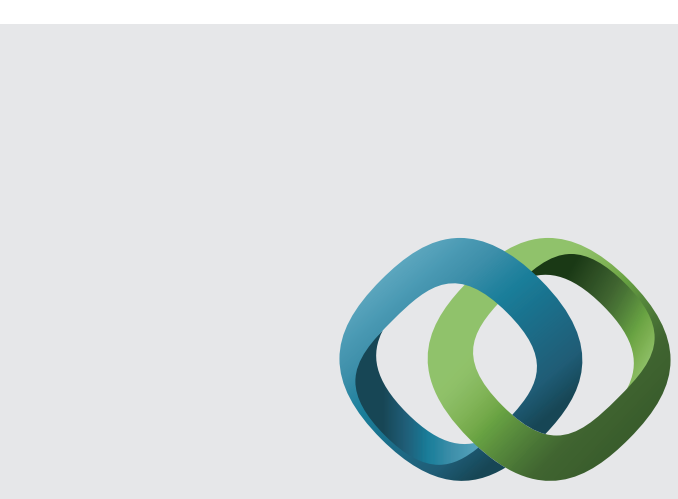

\section{Hindawi}

Submit your manuscripts at

http://www.hindawi.com
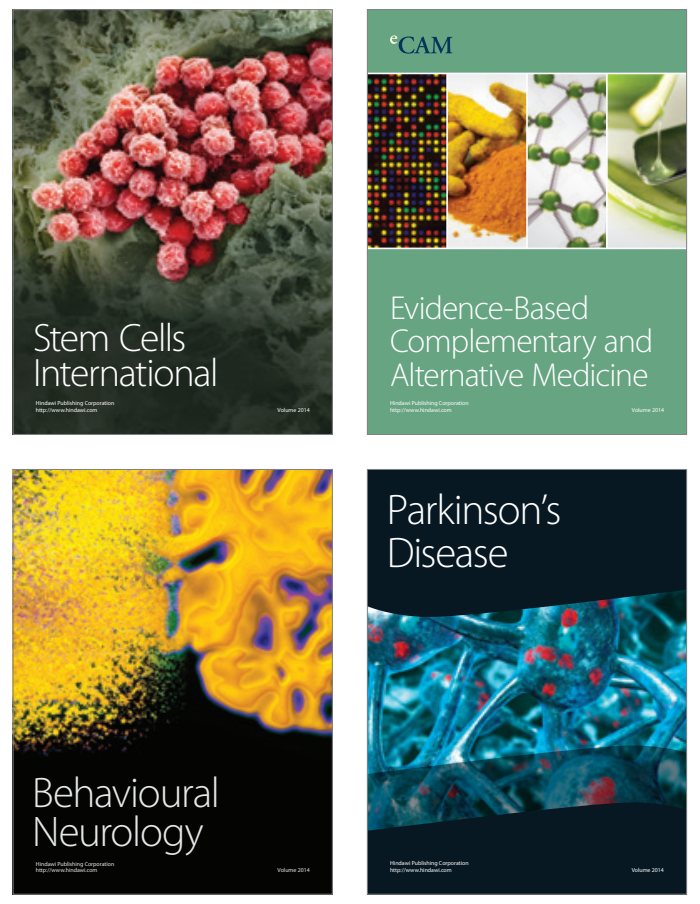
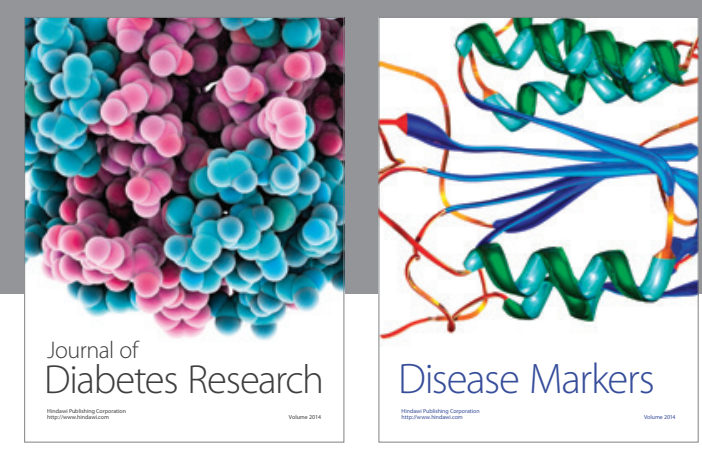

Disease Markers
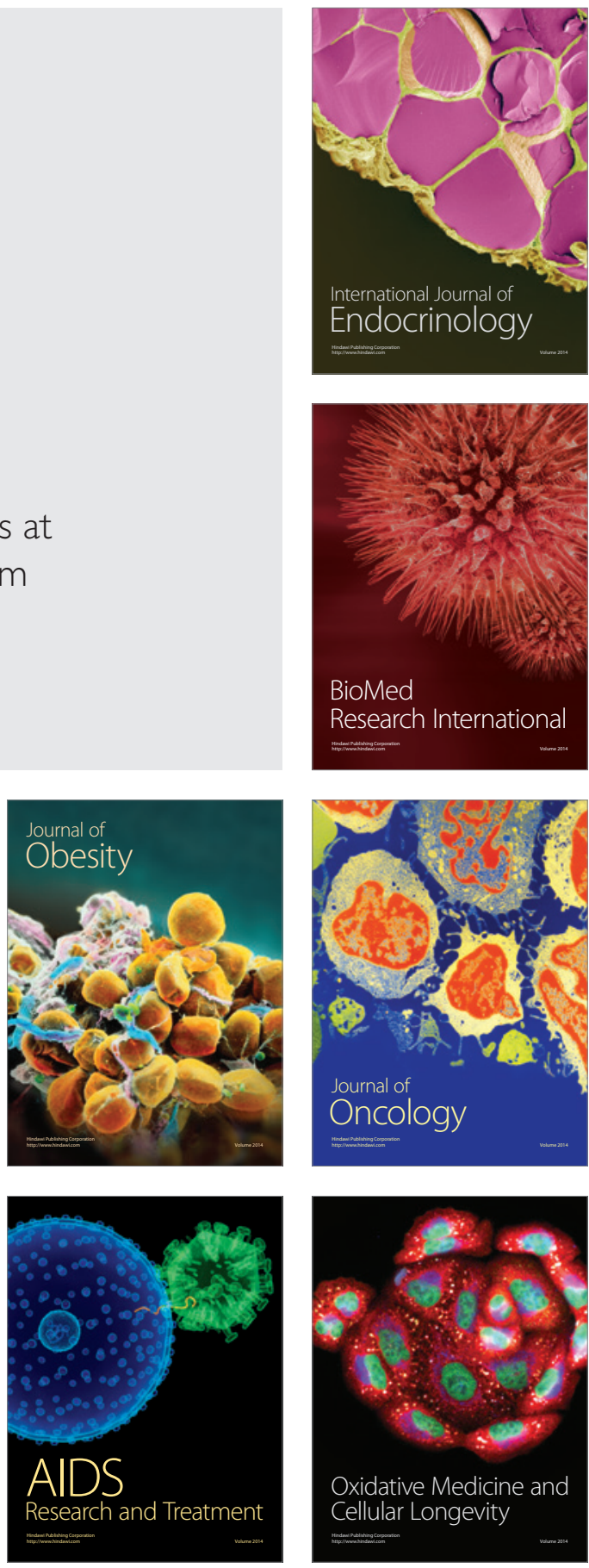